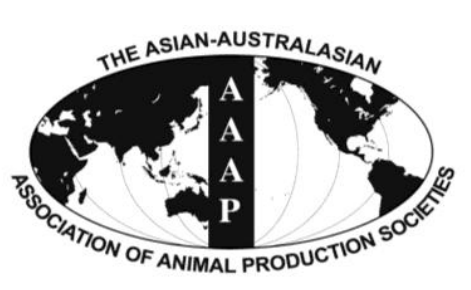

Open Access

Asian Australas. J. Anim. Sci.

Vol. 27, No. 2 : 247-255 February 2014

http://dx.doi.org/10.5713/ajas.2013.13319

www.ajas.info

pISSN 1011-2367 elSSN 1976-5517

\title{
Efficacy of Flaxseed Flour as Bind Enhancing Agent on the Quality of Extended Restructured Mutton Chops
}

\author{
Heena Sharma*, Brahma Deo Sharma, S. K. Mendiratta, Suman Talukder, and Giriprasad Ramasamy \\ Division of Livestock Products Technology, Indian Veterinary Research Institute, Bareilly-243 122, U.P., India
}

\begin{abstract}
Consumers have become very conscious about their nutrition and well being due to changes in their socio-economic lifestyle and rapid urbanization. Therefore, development of technology for production of low cost and functional meat products is urgently required. One such approach is innovative restructuring technology in which binding of meat pieces still remains the main challenge and extension of product is generally associated with poor binding and texture. Thus, the present study was envisaged as an attempt to solve this problem by the incorporation of flaxseed flour (FF) as bind enhancing agent. The FF was used at three different levels viz., $0.5 \%, 1 \%$, and $1.5 \%$ to replace lean meat in pre-standardized restructured mutton chops formulation. The products were subjected to analysis for physico-chemical, sensory and textural properties. Cooking yield, moisture percentage and fat percentage increased with increase in the level of incorporation of FF, however, protein percent and $\mathrm{pH}$ decreased with increase in the level of incorporation. Shear force value of product incorporated with $1.5 \%$ FF was significantly higher $(\mathrm{p}<0.01)$ than control and product containing $0.5 \% \mathrm{FF}$ level. Among the sensory attributes, product with $1 \%$ flaxseed flour showed significantly higher values $(\mathrm{p}<0.05)$ for general appearance, binding, texture and overall acceptability. Hardness showed significant increasing $(\mathrm{p}<0.01)$ values with increasing levels of incorporation of flaxseed flour, however all other parameters of texture profile analysis showed a decreasing trend. On the basis of sensory scores and physico-chemical properties, the optimum incorporation level of FF was adjudged as $1 \%$. Products incorporated with optimum level of flaxseed flour $(1 \%)$ were also assessed for water activity and microbiological quality during the storage period of 15 days. It was found that the extended restructured product could be safely stored under refrigeration $\left(4^{\circ} \mathrm{C} \pm 1^{\circ} \mathrm{C}\right)$ in low density polyethylene (LDPE) pouches for 15 days without marked deterioration in sensory and microbiological quality. Thus, it was concluded that flaxseed flour can be used as a good bind enhancing agent in extended restructured meat products at an economic cost. (Key Words: Flaxseed Flour, Restructured Mutton Chops, Physico-chemical Properties, Sensory Attributes, Texture Profile Analysis, Microbiological Quality)
\end{abstract}

\section{INTRODUCTION}

Sheep meat is a good source of valuable nutrients. Unlike pork and beef, it has no social taboos and is consumed by all the religions and races in the country, thus making it the most preferred meat in India. India has $6.1 \%$ of the world's sheep population and contributes $2.8 \%$ of the world's mutton production. Therefore, there is a huge scope for better utilization of mutton in the development of convenient and innovative products like restructured products. Restructured meat products are highly acceptable

\footnotetext{
* Corresponding Author: Heena Sharma. Tel: +917599058135, E-mail: heena_vet@yahoo.com

Submitted May 21, 2013; Accepted Aug. 5, 2013; Revised Sept. 2, 2013
}

by the modern consumers due to their convenience and balanced nutritional aspect along with its scope of added functionality. Incorporation of different extenders in the form of functional ingredients in processed mutton products is in common practice by commercial meat processors. However, binding remains one of the problems associated with reduced consumer's acceptability of restructured products (Boles and Shand, 1999). Therefore, application of various easily available natural bind enhancers in restructured mutton products could solve the problem. Flaxseed flour $(\mathrm{FF})$ is one of the ingredients that has the potential to be used in extended restructured mutton chops (ERMC) development (Singh et al., 2011).

FF is ranked among the very important functional foods because of its very high content of alpha-linoloenic acid

Copyright $@ 2014$ by Asian-Australasian Journal of Animal Sciences This is an open-access article distributed under the terms of the Creative Commons Attribution Non-Commercial License (http://creativecommons.org/licenses/by-nc/3.0/), which permits unrestricted non-commercial use, distribution, and reproduction in any medium, provided the original work is properly cited. 
(ALA), dietary fiber, lignin, flavonoids, phenolics and good quality protein (Berglund, 2002). It is unique among oil seeds due to its high content of mucilage and gums in the outer layer of seeds and contains mainly xylose, rhamnose, galactose, glucose, arabinose, fucose and galacturonic acid (Chen et al., 2007). The whole seed and oil of flax have been used for edible purposes in some European and Asian countries. According to Daun et al. (2003), flaxseed oil usually contains greater than $50 \%$ of ALA. There is more information on the use of flaxseed in bakery products (Lipilina and Ganj, 2009) and meat products (Valencia et al., 2008). The water binding and emulsifying properties of flaxseed mucilage have contributed to its use in selected food systems (i.e fish sauce, ice-creams and meat emulsions) (Singer et al., 2011). The characteristics of mutton such as high biological protein, vitamins and minerals (Williams, 2007) and its increasing demand in domestic and foreign markets provide a wide scope for research and development of newer type products with higher functionality and acceptability. There is a growing awareness among meat consumers of nutritional diseases and the correlation between food habits and health. Healthier foods should include functional ingredients which increase the acceptability of product among consumers. Therefore, there is a need for the development of low cost and functional meat products. One such approach is the innovative restructuring technology which has the advantages of convenience in preparation and economy in production. A number of researchers have been working on development and incorporation of restructured meat products and they generally observe binding as a major problem. This problem is further compounded with extension of restructured products which is done to decrease the cost of production. The same problem lies with the manufacturers who generally incorporate non-meat ingredients to earn margin of profit. Incorporation of extenders (non-meat ingredients) in product preparation results in poor binding, and thus, decreased palatability of product. Therefore, manufacturers often encounter the problem of binding in their restructured meat products.

Since, mutton has not been much explored in this regard; the present study was conducted in order to utilize flaxseed flour as bind enhancing agent in restructured meat product i.e extended restructured mutton chops. Therefore, extended restructured mutton chops were prepared with extenders which would also keep their cost at an affordable level.

\section{MATERIALS AND METHODS}

\section{Procurement of mutton and ribs}

Slaughtered sheep aged 1 to 2 years, of either sex, were brought and dressed in Experimental Abattoir of LPT
Division, IVRI, Bareilly, Uttar Pradesh, India. After manual deboning, mutton was packaged in clean polyethylene bags and brought to the laboratory under refrigerated conditions. Ribs were also collected at same time from the abattoir and the meat cleaned off with a knife. Deboned mutton and ribs were finally stored overnight at $4^{\circ} \mathrm{C} \pm 1^{\circ} \mathrm{C}$ in a refrigerator and then stored frozen at $-20^{\circ} \mathrm{C}$ till further use.

\section{Flaxseed flour and other ingredients}

Flaxseed was purchased from local market of Bareilly, dried and then powdered in a grinder and used for study purpose. For the preparation of condiments, onion was peeled, cut into small pieces and homogenized in a mixer to obtain a fine paste. Condiments provide a good aroma and flavour to product as well as provide a suitable medium to extract salt soluble proteins. Refined salt (Tata Chemicals Ltd., Mumbai), refined wheat flour (Maida) and potato were procured from the local market of Bareilly. Other additives used were peahull flour (PHF), sodium nitrite (Merck Specialities Pvt. Ltd., Mumbai), sodium tripolyphophate, and spice mix. PHF was prepared by grinding dried peahulls (hull obtained from pea vegetable) to the consistency of flour followed by sieving. The different spice ingredients used for preparation of spice mix were mixed in suitable proportion as per pre-standardized formulation reported by Verma et al. (2010).

\section{Packaging materials}

Low density polyethylene (LDPE) films (200 gauges) were purchased from M/s Hitkari Industries Ltd., New Delhi, India and used for aerobic packaging of the product during refrigerated storage and for storage studies.

\section{Preparation of extended restructured mutton chops}

Frozen mutton in LDPE packages was partially thawed (approx. $16 \mathrm{~h}$ at $4^{\circ} \mathrm{C} \pm 1^{\circ} \mathrm{C}$, reaching between $-3^{\circ} \mathrm{C}$ and $-5^{\circ} \mathrm{C}$ ) and carefully trimmed free of adhering visible loose connective tissue. Meat chunks in a semi frozen state were placed in paddle mixer (HOBART, Model: N50G) for massaging which was done initially at low speed with simultaneous addition of salt, sodium nitrite and sodium tripolyphosphate dissolved in chilled water which facilitated the extraction of muscle proteins from meat and formed a tacky exudate to bind meat pieces. After 4 min of initial mixing at speed setting 2, refined wheat flour, spices, and condiments were added one by one. Then, PHF (hydrated 1:1) and boiled mashed potato (BMP) were added and concurrently mixed/blended for an additional $2 \mathrm{~min}$ for uniform mixing. Once each mixing time was achieved, the mix was unloaded from the mixer and each $100 \mathrm{~g}$ of mix was bound to one rib to produce extended restructured mutton chop. Chops, thus prepared, were wrapped in 
aluminium foil and kept for cooking (broiling) at $250^{\circ} \mathrm{C}$ for $40 \mathrm{~min}$ in broiler so as to achieve internal temperature of $85^{\circ} \mathrm{C}$.

Thus, the pre-standardized formulation (w/w) of extended restructured mutton chops included lean Meat $(66 \%)$, ice/chilled water $(12 \%)$, refined wheat flour $(3 \%)$, salt $(1.75 \%)$, spice mix $(1.75 \%)$, condiments $(5 \%)$, sodium nitrite (150 ppm), sodium polyphosphate (0.5\%), BMP (5\%), PHF (5\%).

\section{Detailed study}

In the present study, flaxseed flour (FF) was used at three different levels viz., $0.5 \%$ (T-I), $1 \%$ (T-II) and $1.5 \%$ (T-III) in extended restructured mutton chops by replacing lean meat the in pre-standardized restructured mutton chops formulation. The resultant products were analyzed and compared for various physic-chemical, textural and sensory properties against control which was a pre-standardized extended restructured mutton chops without any bind enhancing agent and then, the optimum level of FF incorporation was selected for further estimation of water activity and microbiological studies.

\section{Product analysis}

Sample preparation: Six samples (duplicate in three batches) for all four products (control and three treatments) were evaluated for various parameters such as $\mathrm{pH}$, cooking yield, proximate composition, texture profile analysis, water activity and microbiology quality. However, in the case of estimating the shear force value, 30 samples were analysed (ten samples in three batches) and for sensory evaluation, analysis of 21 samples ( 7 samples in three batches) was conducted.

pH determination and cooking yield: $\mathrm{pH}$ of extended restructured mutton chops was determined by the method described by Trout et al. (1992) in which $10 \mathrm{~g}$ of sample was blended with $50 \mathrm{~mL}$ of distilled water using a tissue homogenizer. The $\mathrm{pH}$ of suspension was recorded by immersing combined glass electrode of an Elico digital $\mathrm{pH}$ meter, Model LI 127 (Elico Limited Hyderabad, India). The product yield was obtained by measuring weight of mutton chops for control as well as each treatment and calculating the ratio of cooked weight and raw weight and expressed as percentage.

Proximate analysis: Moisture, crude fat, protein and ash of the product were determined as per the standard procedures of Association of Official Analytical Chemists (AOAC, 1995). The ratio between moisture and protein was also calculated. Shear force value was determined as per Berry and Stiffler (1981), as the force required for shearing $1 \mathrm{~cm}$ square block measured in $\mathrm{kg}$ on Warner-Bratzler Shear Press (GR Elec. MFG. Co.). Water activity of extended restructured mutton chops were measured by $a_{w}$ meter (Hygrolab 3, Rotronics, Switzerland).

Texture profile analysis (TPA): Textural properties of cooked samples were determined using the TPA procedure of Bourne (1967) and an instrumental texture profile analyzer (TA HD plus Texture Analyzer) at GBPUA\&T, Pantnagar. The parameters studied were hardness, adhesiveness, springiness, gumminess, cohesiveness and chewiness. Chilled samples were tempered to room temperature and were cut into $1 \mathrm{~cm}$ squares. The samples were placed on a platform in a fixture and compressed twice to $85 \%$ of their original height by a compression probe (P75) at a cross head speed of $10 \mathrm{~mm} / \mathrm{s}$ through a two cycle sequence, using a $50 \mathrm{~kg}$ load cell.

Sensory analysis: A sensory evaluation method using an 9 point hedonic scale (Lim, 2011) was followed, where 9= like extremely; 1 = dislike extremely. The sensory panel consisted of seven trained scientists and post graduate students of the division. Three digit coded samples were served to the panelists in random order. The nature of experiment was explained to the panel without disclosing the identity of the samples. Taste panel were organized around 3.30 to $4.00 \mathrm{pm}$ every time. The sensory panellists were asked to rate their preference on 9 point descriptive scale on the sensory evaluation proforma for general appearance, flavour, juiciness, texture, binding and overall palatability. Plain water was provided to rinse the mouth between the samples.

\section{Storage study}

Extended restructured mutton chops were prepared by incorporating the optimum level of bind enhancing agent; flaxseed flour $(1 \%)$, packed in LDPE bags and stored at refrigeration temperature $\left(4^{\circ} \mathrm{C} \pm 1^{\circ} \mathrm{C}\right)$. The products were evaluated for 15 days at an interval of 5 days for the sensory attributes, physico-chemical parameters ( $\mathrm{pH}$ and Thiobarbituric Acid Reacting Substances (TBARS) and microbiological parameters (Total Plate Count (TPC), Psychrophilic Count (PC) and Coliform count).

Thiobarbituric acid reacting substances value (TBARS value): The TBARS Value of mutton chops was determined by using the distillation method described by Tarladgis et al. (1960). The optical density (OD) was recorded using spectrophotometer (Model: Beckman DU 40) at $538 \mathrm{~nm}$. The OD was multiplied by the factor 7.8 and TBARS value was expressed as mg malonaldehyde $/ \mathrm{kg}$ of sample.

Total plate count, psychrophilic count and coliform count: TPC, PC and coliform count in the samples were determined following methods as described by APHA (1984). Readymade media (Hi-Media, India) were used for all microbiological examinations. 


\section{Statistical analysis}

The statistical design of the study was 4 (treatments) $\mathrm{X}$ 3 (replications) randomized block design. All physical and chemical determinations were done in triplicate. There were seven sensory determinations for each treatment-replication combination. The data generated from various trials under experiment were pooled, processed and analyzed by statistical method of one way-ANOVA and mean \pm SE using SPSS software package developed as per the procedure of Snedecor and Cochran (1995). Duncan's multiple range test (Duncan, 1955) and critical difference were determined at the 5\% significance level. Sensory data was also analyzed using same procedure for each attribute separately.

\section{RESULTS AND DISCUSSION}

\section{Cooking yield, $\mathrm{pH}$ and proximate analysis}

Cooking yield of control and all treatment products did not differ significantly, however, the gradual increase in cooking yield of treatment products might be attributed to the gelatinising property of starch component on heating, which prevented evaporative moisture loss during cooking (Table 1). Chen et al. (2004) also reported that flaxseed had good water holding capacity. There was a non-significant decrease in $\mathrm{pH}$ values as the levels of FF increased. Bilek and Turhan (2009) also reported that the addition of FF did not significantly affect $\mathrm{pH}$ values of raw and cooked beef patties. Lean meat replacement with $\mathrm{FF}$ at an increasing level caused a non-significant increase in moisture content of ERMC, which might have been due to formation of thermo-reversible gels by flaxseed gum (Chen et al., 2006). The percentage protein in treatment products was similar to control and decreased slightly due to replacement of lean meat with a fat rich ingredient. As expected, addition of FF increased the fat content of product significantly due to higher fat content of FF (37.13\%). Increase in the total fat of product on addition of flaxseed had also been reported by Singh et al. (2011). Ash content of treatment products was almost similar to control. Similar results were obtained by Turhan et al. $(2005 ; 2007)$ in low fat beef burgers and low fat beef patties respectively. There was non-significant increase in moisture to protein ratio of products with an increasing level of FF. Shear force value of T-III was significantly higher than control, T-I and T-II which could be attributed to gel formation by flaxseed. Chen et al. (2004) reported that the high viscosity of flaxseed gum in aqueous solutions and interaction between meat proteins and flaxseed gum was also found to be a desirable trait (Chen et al., 2006). The major forces responsible for this interaction are electrostatic in nature (Bernal et al., 1987) and are involved in the formation of salt soluble meat protein and flaxseed gum mixture gels. Polysaccharides used as water binders in meat products have been found to affect the thermal transition temperature of meat proteins. Chen et al. (2006) have reported an increased transition temperature of salt soluble meat protein on addition of flaxseed gum which indicated the possible interaction between salt soluble meat proteins and flaxseed gum.

\section{Textural characteristics}

Textural profile analysis revealed a significant increase in hardness with replacement of lean meat with FF which was probably due to increased shear force value of product and binding strength, which indicates binding efficiency of flaxseed flour (Table 2). However incorporation of FF in extended restructured mutton chops resulted in nonsignificant increase in springiness and cohesiveness of the product which could be due to a better gelling nature of carbohydrates present in FF. Adhesiveness, gumminess and chewiness of treatment products recorded significantly lower values which were expected due to melting characteristics of hydrocolloid gel (Holmes et al., 1986).

Table 1. Physico-chemical properties of extended restructured mutton chops incorporated with different levels of flaxseed flour (Mean \pm SE)*

\begin{tabular}{|c|c|c|c|c|}
\hline Parameters & Control & T-I & T-II & T-III \\
\hline${\text { Cooking yield }(\%)^{1}}^{1}$ & $86.24 \pm 0.69$ & $86.49 \pm 0.98$ & $87.52 \pm 0.79$ & $87.93 \pm 0.72$ \\
\hline $\mathrm{pH}^{1}$ & $6.32 \pm 0.05$ & $6.26 \pm 0.29$ & $6.23 \pm 0.43$ & $6.23 \pm 0.43$ \\
\hline Moisture (\%) ${ }^{1}$ & $67.75 \pm 0.35$ & $68.29 \pm 1.30$ & $68.77 \pm 0.79$ & $69.44 \pm 0.35$ \\
\hline Protein $(\%)^{1}$ & $20.21 \pm 0.48$ & $20.23 \pm 0.28$ & $19.76 \pm 0.39$ & $19.44 \pm 0.36$ \\
\hline $\operatorname{Fat}(\%)^{1}$ & $4.58 \pm 0.37^{\mathrm{c}}$ & $5.59 \pm 0.17^{b}$ & $6.61 \pm 0.44^{\mathrm{a}}$ & $6.64 \pm 0.21^{\mathrm{a}}$ \\
\hline $\operatorname{Ash}(\%)^{1}$ & $2.51 \pm 0.07$ & $2.53 \pm 0.03$ & $2.60 \pm 0.09$ & $2.63 \mathrm{v} 0.07$ \\
\hline Moisture:protein ratio ${ }^{1}$ & $3.36 \pm 0.08$ & $3.38 \pm 0.08$ & $3.49 \pm 0.09$ & $3.58 \pm 0.05$ \\
\hline Shear force value $\left(\mathrm{kg} / \mathrm{cm}^{2}\right)^{2}$ & $0.65 \pm 0.03^{c}$ & $0.76 \pm 0.02^{\mathrm{b}}$ & $0.81 \pm 0.02^{\mathrm{b}}$ & $0.90 \pm 0.02^{\mathrm{a}}$ \\
\hline
\end{tabular}

* Mean \pm SE with different superscripts in a row differ significantly $(\mathrm{p}<0.01)$.

${ }^{1} \mathrm{n} 1=6,{ }^{2} \mathrm{n} 2=30$ for each treatment. Control = Extended restructured mutton chops.

$\mathrm{T}-\mathrm{I}=$ Extended restructured mutton chops with flaxseed flour $0.5 \mathrm{~g} / 100 \mathrm{~g}$ formulation.

$\mathrm{T}-\mathrm{II}=$ Extended restructured mutton chops with flaxseed flour $1 \mathrm{~g} / 100 \mathrm{~g}$ formulation.

$\mathrm{T}$-III $=$ Extended restructured mutton chops with flaxseed flour $1.5 \mathrm{~g} / 100 \mathrm{~g}$ formulation. 
Table 2. Texture profile of extended restructured mutton chops with different levels of flaxseed flour (Mean $\pm \mathrm{SE}$ )*

\begin{tabular}{lcccc}
\hline Parameters & Control & T-I & T-II & T-III \\
\hline Hardness $\left(\mathrm{N} / \mathrm{cm}^{2}\right)$ & $53.67 \pm 3.05^{\mathrm{c}}$ & $58.10 \pm 1.55^{\mathrm{bc}}$ & $60.87 \pm 1.35^{\mathrm{ab}}$ & $64.54 \pm 1.37^{\mathrm{a}}$ \\
Adhesiveness (Ns) & $-0.10 \pm 0.003^{\mathrm{a}}$ & $-0.10 \pm 0.004^{\mathrm{ab}}$ & $-0.11 \pm 0.003^{\mathrm{b}}$ & $-0.11 \pm 0.002^{\mathrm{b}}$ \\
Springiness $(\mathrm{cm} / \mathrm{mm})$ & $0.21 \pm 0.008$ & $0.23 \pm 0.01$ & $0.23 \pm 0.008$ & $0.23 \pm 0.008$ \\
Cohesiveness & $0.49 \pm 0.007$ & $0.50 \pm 0.007$ & $0.51 \pm 0.008$ & $0.52 \pm 0.01$ \\
Gumminess $\left(\mathrm{N} / \mathrm{cm}^{2}\right)$ & $34.40 \pm 0.68^{\mathrm{a}}$ & $30.32 \pm 0.50^{\mathrm{b}}$ & $28.25 \pm 0.64^{\mathrm{c}}$ & $26.35 \pm 0.60^{\mathrm{d}}$ \\
Chewiness $(\mathrm{N} / \mathrm{cm})$ & $6.79 \pm 0.006^{\mathrm{a}}$ & $6.31 \pm 0.006^{\mathrm{b}}$ & $5.82 \pm 0.14^{\mathrm{c}}$ & $5.49 \pm 0.21^{\mathrm{c}}$ \\
\hline
\end{tabular}

* Mean \pm SE with different superscripts in a row differ significantly $(\mathrm{p}<0.01)$.

$\mathrm{n}=6$ for each treatment. Control $=$ Extended restructured mutton chops.

$\mathrm{T}-\mathrm{I}=$ Extended restructured mutton chops with flaxseed flour $0.5 \mathrm{~g} / 100 \mathrm{~g}$ formulation.

$\mathrm{T}-\mathrm{II}=$ Extended restructured mutton chops with flaxseed flour $1 \mathrm{~g} / 100 \mathrm{~g}$ formulation.

$\mathrm{T}-\mathrm{III}=$ Extended restructured mutton chops with flaxseed flour $1.5 \mathrm{~g} / 100 \mathrm{~g}$ formulation.

Table 3. Sensory attributes of extended restructured mutton chops incorporated with different levels of flaxseed flour (Mean \pm SE)*

\begin{tabular}{lcccc}
\hline Sensory attributes & Control & T-I & T-II & T-III \\
\hline General appearance & $7.96 \pm 0.07^{\mathrm{c}}$ & $8.18 \pm 0.06^{\mathrm{bc}}$ & $8.41 \pm 0.09^{\mathrm{a}}$ & $8.25 \pm 0.07^{\mathrm{ab}}$ \\
Flavour & $7.93 \pm 0.04$ & $8.05 \pm 0.06$ & $7.99 \pm 0.05$ & $7.94 \pm 0.09$ \\
Binding & $7.57 \pm 0.06^{\mathrm{c}}$ & $7.78 \pm 0.05^{\mathrm{b}}$ & $8.03 \pm 0.04^{\mathrm{a}}$ & $8.01 \pm 0.06^{\mathrm{a}}$ \\
Texture & $7.68 \pm 0.04^{\mathrm{c}}$ & $7.81 \pm 0.05^{\mathrm{bc}}$ & $8.00 \pm 0.05^{\mathrm{a}}$ & $7.98 \pm 0.07^{\mathrm{ab}}$ \\
Juiciness & $7.90 \pm 0.04$ & $7.93 \pm 0.05$ & $8.03 \pm 0.05$ & $7.90 \pm 0.04$ \\
Overall acceptability & $7.85 \pm 0.04^{\mathrm{c}}$ & $7.91 \pm 0.03^{\mathrm{bc}}$ & $8.15 \pm 0.04^{\mathrm{a}}$ & $8.04 \pm 0.05^{\mathrm{ab}}$ \\
\hline
\end{tabular}

* Mean \pm SE with different superscripts in a row differ significantly $(\mathrm{p}<0.01)$.

Based on 9-point hedonic scale where 1: extremely disliked and 9: extremely liked.

$\mathrm{n}=21$ for each treatment. Control $=$ Extended restructured mutton chops.

$\mathrm{T}-\mathrm{I}=$ Extended restructured mutton chops with flaxseed flour $0.5 \mathrm{~g} / 100 \mathrm{~g}$ formulation.

$\mathrm{T}-\mathrm{II}=$ Extended restructured mutton chops with flaxseed flour $1 \mathrm{~g} / 100 \mathrm{~g}$ formulation.

$\mathrm{T}-\mathrm{III}=$ Extended restructured mutton chops with flaxseed flour $1.5 \mathrm{~g} / 100 \mathrm{~g}$ formulation.

\section{Sensory scores}

Sensory evaluation of products revealed that replacement of lean meat with FF affected appearance, binding, texture and overall acceptability (Table 3). However, flavour and juiciness scores were comparable to control. Incorporation of flaxseed flour resulted in an overall increase in all the sensory scores. Among treatments, the product with $1 \%$ FF had highest sensory ratings, where all scores were close to very much like (ranging from 7.99 to 8.41). A slight yellowish brown colour of FF could be a contributing factor for higher general appearance score. Reduction in flavour scores with increasing levels of FF might be due to dilution of meaty flavour. The significant increase in binding scores might be due to increased viscosity of samples by incorporation of FF (Wang et al., 2011). Higher juiciness scores in treatment products might be due to melting characteristics of hydrocolloid gels which had an effect on flavour release and perception of juiciness (Holmes et al., 1986). The higher general appearance, flavour, binding and texture appear to have contributed to the significantly higher overall acceptability score for T-II.

On the basis of physico-chemical and sensory attributes, ERMC incorporated with $1 \% \mathrm{FF}$ were adjudged as most acceptable among treatment products and thus, selected as the optimum level for further water activity estimation and microbiological studies.

\section{Water activity}

The flaxseed flour incorporated ERMC showed a significantly lower $(\mathrm{p}<0.05)$ values than control product (Figure 1). The lower water activity $\left(a_{w}\right)$ of treatment product indicated higher storage stability of product.

\section{Microbiological analysis}

$p H$ : There was non-significant increase in $\mathrm{pH}$ values of control and treatment products with increase in storage period due to degradation of carbohydrates present in the bind enhancing agents. However, a significantly higher $\mathrm{pH}$ $(\mathrm{p}<0.01)$ was observed in the control than in the treatment product (Table 4). Acidic nature of flaxseed flour could be the contributory factor for reduction in $\mathrm{pH}$ of treatment product.

Thiobarbituric acid reacting substances (TBARS) value: Mean score values for TBARS showed a significant increase $(p<0.05)$ in values for both control and treatment product with increasing storage period (Table 4). This was expected due to the increased lipid oxidation and production of volatile metabolites in the presence of oxygen during aerobic storage (Modi et al., 2004). However, the values were within the acceptable limit of $1 \mathrm{mg}$ malonaldehyde/kg 


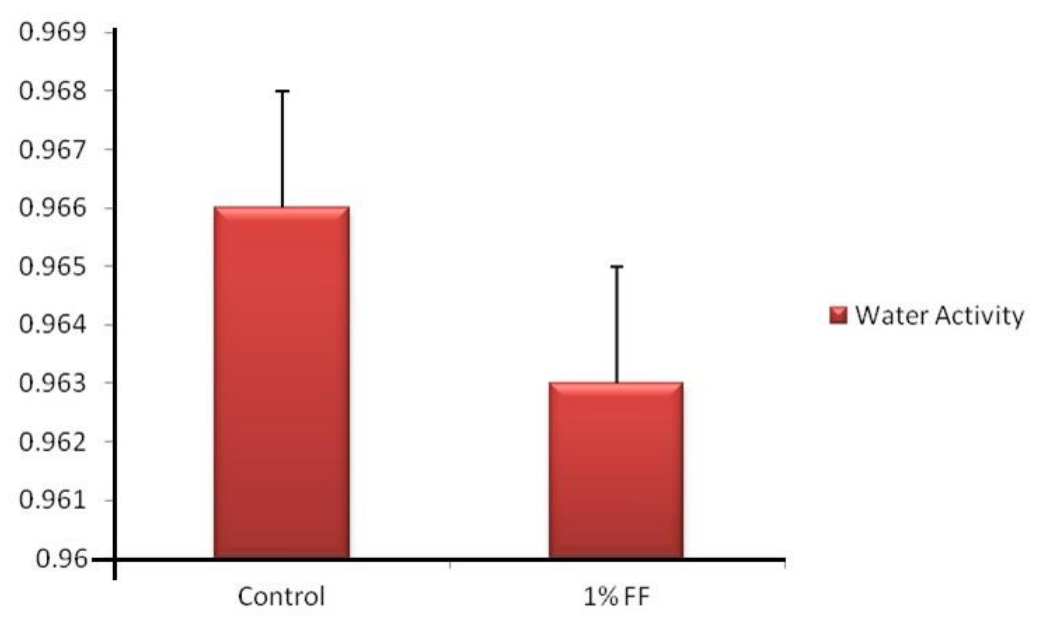

Figure 1. Effect of optimum level of flaxseed flour on water activity of extended restructured mutton chops $(\mathrm{n}=6$ for each treatment).

meat (Watts, 1962). Tarladgis et al. (1960) also reported that the minimum threshold value of TBARS in cooked meat products during storage was 0.50 to $1.0 \mathrm{mg}$, as detected by a trained panel and a range of 0.6 to $2 \mathrm{mg}$ was considered to be the detectable minimum level for off-flavour by inexperienced panelists (Greene and Cumuze, 1982). As expected TBARS values treatment product always remained below when compared to control due to anti-oxidant property of dietary fiber in flaxseed flour (Fiscus et al., 1999).

Psychrophilic count: Psychrophilic microbes were not detected on 0 day of storage either in control or treatment product, which was probably due to destruction of psychrophiles during cooking (Table 4). These microbes were detected on 5th day of storage and significantly higher count $(p<0.05)$ was observed on 10th and 15 th day of storage and was attributed to the recovery of injured organisms and then multiplication during subsequent period of storage. There was no significant difference $(p>0.05)$ between control and treatment product throughout the storage period. However, psychrophilic counts always remained within the permissible limits in cooked meat products of $\log _{10} 4.6 \mathrm{cfu} / \mathrm{g}$ as reported by Cremer and Chipley (1977) thus, indicating the acceptability of product till 15 days. The limit of psychrotrophic counts that could cause microbiological spoilage of stored meat products has been reported as $\log _{10} 4 \mathrm{cfu} / \mathrm{g}$ (Jay, 1996).

Total plate count: Total plate count followed a significant increasing trend $(\mathrm{p}<0.05)$ from 0 to 15 th day of refrigerated storage in treatment product as well as control

Table 4. Effect of refrigerated storage on physico-chemical characteristics and microbiological count of aerobically packaged extended restructured mutton chops incorporated with flaxseed flour (Mean $\pm \mathrm{SE}) *$

\begin{tabular}{|c|c|c|c|c|}
\hline \multirow{2}{*}{ Treatments } & \multicolumn{4}{|c|}{ Refrigerated storage period (days) } \\
\hline & 0 & 5 & 10 & 15 \\
\hline \multicolumn{5}{|l|}{$\overline{\mathrm{pH}}$} \\
\hline Control & $6.33 \pm 0.007^{\mathrm{b} 1}$ & $6.34 \pm 0.005^{\mathrm{b} 1}$ & $6.34 \pm 0.005^{\mathrm{b} 1}$ & $6.36 \pm 0.002^{\mathrm{a} 1}$ \\
\hline Flaxseed flour (1\%) & $6.22 \pm 0.009^{\mathrm{b} 2}$ & $6.23 \pm 0.007^{\mathrm{ab} 2}$ & $6.24 \pm 0.005^{\mathrm{ab} 2}$ & $6.24 \pm 0.002^{\mathrm{a} 2}$ \\
\hline \multicolumn{5}{|c|}{ TBARS values (mg malonaldehyde/kg) } \\
\hline Control & $0.18 \pm 0.01^{\mathrm{d}}$ & $0.27 \pm 0.01^{\mathrm{c}}$ & $0.32 \pm 0.01^{\mathrm{b}}$ & $0.39 \pm 0.02^{\mathrm{a}}$ \\
\hline Flaxseed flour $(1 \%)$ & $0.16 \pm 0.02^{\mathrm{d}}$ & $0.23 \pm 0.01^{\mathrm{c}}$ & $0.31 \pm 0.02^{\mathrm{b}}$ & $0.37 \pm 0.01^{\mathrm{a}}$ \\
\hline \multicolumn{5}{|c|}{ Psychrophilic count $\left(\log _{10} \mathrm{cfu} / \mathrm{gm}\right)$} \\
\hline Control & Not detected & $0.72 \pm 0.23^{\mathrm{b}}$ & $1.66 \pm 0.09^{\mathrm{ab}}$ & $2.74 \pm 0.03^{\mathrm{a}}$ \\
\hline Flaxseed flour (1\%) & Not detected & $0.55 \pm 0.25^{\mathrm{b}}$ & $1.68 \pm 0.08^{\mathrm{a}}$ & $2.71 \pm 0.02^{\mathrm{a}}$ \\
\hline \multicolumn{5}{|c|}{ Total plate count $\left(\log _{10} \mathrm{cfu} / \mathrm{gm}\right)$} \\
\hline Control & $1.50 \pm 0.05^{\mathrm{d}}$ & $2.28 \pm 0.06^{\mathrm{c} 12}$ & $2.59 \pm 0.02^{\mathrm{b} 1}$ & $2.91 \pm 0.03^{\mathrm{a} 1}$ \\
\hline Flaxseed flour (1\%) & $1.62 \pm 0.05^{\mathrm{d}}$ & $2.16 \pm 0.03^{\mathrm{c} 2}$ & $2.38 \pm 0.02^{\mathrm{b} 2}$ & $2.78 \pm 0.02^{\mathrm{a} 12}$ \\
\hline \multicolumn{5}{|c|}{ Coliform count $\left(\log _{10} \mathrm{cfu} / \mathrm{gm}\right)$} \\
\hline Control & Not detected & Not detected & Not detected & Not detected \\
\hline Flaxseed flour (1\%) & Not detected & Not detected & Not detected & Not detected \\
\hline
\end{tabular}

* Mean \pm SE with different superscripts row wise (alphabet) and column wise (numeral) differ significantly ( $\mathrm{p}<0.01$ ).

$\mathrm{n}=6$ for each treatment. 
(Table 4); however these counts were well below the permissible limit i.e. $\log _{10} 7 \mathrm{cfu} / \mathrm{g}$ for cooked meat products (Jay, 1996). There was no significant difference $(p>0.05)$ noticed in TPC between control and ERMC incorporated with flaxseed flour except on 10th day of storage period where TPC of the treatment product was comparatively lower $(p>0.05)$ than that of control. However, like PC, TPC of control and treatment product always remained below $\log _{10} 5.33 \mathrm{cfu} / \mathrm{g}$ which is indicative of unacceptability of cooked meat products (Cremer and Chipley, 1977).

Coliform count: Coliforms were not detected during the entire storage period in either the control or the product with optimum level of flaxseed flour (Table 4). The major contributing factor for the absence of coliforms from product was the adoption of good hygienic practices during and after preparation of products and method of cooking. Futhermore, the cooking of product was done to an internal temperature of $72^{\circ} \mathrm{C}$ which could have resulted in lethal conditions to the coliforms. Similar findings were observed by Sachdev and Gopal (2000) in cooked chicken rolls.

\section{Sensory scores during microbiological study}

Mean sensory scores revealed that replacement of lean meat with $1 \%$ FF affected $(\mathrm{p}<0.01)$ general appearance, binding and texture (Table 5), with the scores being significantly higher for treatment product $(\mathrm{p}<0.01)$. General appearance of treatment product was higher due to the yellowish brown colour imparted by FF. Similarly, a significant increase $(\mathrm{p}<0.01)$ in binding and texture of treatment product as compared to control could be attributed to high viscosity contributed by flaxseed gum. However, all sensory attributes of the product showed significant decrease $(p<0.01)$ with an increase in storage period, except for juiciness. Lower flavour scores could be correlated to an increase in TBA value and free fatty acids in meat products (Tarladgis et al., 1960) under aerobic conditions. Decrease in binding and texture was probably due to breakdown of meat proteins due to higher microbial counts following increased storage time. There was nonsignificant decrease $(p>0.05)$ in juiciness between control and treatment products at each interval of storage period which could be attributed to some loss of moisture during aerobic storage. Reduction in overall acceptability of control and treatment product might have been due to increase in lipid oxidation, pigment oxidation and degradation of proteins and fats in ERMC with advancement in storage period. However, ERMC incorporated with optimum level of bind enhancing agent remained quite acceptable up to 15 th day of storage with the sensory ratings close to like moderately on 15 th day $(7.22$ to 7.62 ).

Flaxseed gum is a hydrocolloid with good waterholding capacity, owing to its marked swelling capacity and high viscosity in aqueous solution. It also has the advantage of a relative low cost compared with most of the commercial gums and a stable world-wide supply.

Table 5. Effect of refrigerated storage on sensory attributes of aerobically packaged extended restructured mutton chops incorporated with flaxseed flour $($ Mean \pm SE)*

\begin{tabular}{|c|c|c|c|c|}
\hline \multirow{2}{*}{ Treatments } & \multicolumn{4}{|c|}{ Refrigerated storage period (days) } \\
\hline & 0 & 5 & 10 & 15 \\
\hline \multicolumn{5}{|l|}{ General appearance } \\
\hline Control & $7.90 \pm 0.06^{\mathrm{a} 2}$ & $7.75 \pm 0.06^{\mathrm{ab} 2}$ & $7.65 \pm 0.08^{\mathrm{bc} 12}$ & $7.44 \pm 0.08^{\mathrm{d} 1,2}$ \\
\hline Flaxseed flour (1\%) & $8.39 \pm 0.05^{\mathrm{a} 1}$ & $7.99 \pm 0.08^{\mathrm{b} 1}$ & $7.80 \pm 0.06^{\mathrm{bc} 1}$ & $7.67 \pm 0.07^{\mathrm{c} 1}$ \\
\hline \multicolumn{5}{|l|}{ Flavour } \\
\hline Control & $7.94 \pm 0.06^{\mathrm{a}}$ & $7.84 \pm 0.05^{\mathrm{ab}}$ & $7.69 \pm 0.06^{\mathrm{bc}}$ & $7.54 \pm 0.05^{\mathrm{c}}$ \\
\hline Flaxseed flour (1\%) & $8.04 \pm 0.06^{\mathrm{a}}$ & $7.94 \pm 0.05^{\mathrm{ab}}$ & $7.81 \pm 0.05^{\mathrm{b}}$ & $7.50 \pm 0.10^{\mathrm{c}}$ \\
\hline \multicolumn{5}{|l|}{ Binding } \\
\hline Control & $7.78 \pm 0.05^{\mathrm{a} 2}$ & $7.68 \pm 0.07^{\mathrm{ab} 2}$ & $7.64 \pm 0.07^{\mathrm{ab} 1}$ & $7.49 \pm 0.08^{\mathrm{b}}$ \\
\hline Flaxseed flour (1\%) & $8.25 \pm 0.03^{\mathrm{a} 1}$ & $8.09 \pm 0.04^{\mathrm{a} 1}$ & $7.77 \pm 0.09^{\mathrm{b} 1,2}$ & $7.62 \pm 0.05^{\mathrm{b}}$ \\
\hline \multicolumn{5}{|l|}{ Texture } \\
\hline Control & $7.78 \pm 0.05^{\mathrm{a} 2}$ & $7.67 \pm 0.06^{\mathrm{ab} 2}$ & $7.51 \pm 0.07^{\mathrm{bc} 2}$ & $7.37 \pm 0.07^{\mathrm{c} 2}$ \\
\hline Flaxseed flour (1\%) & $8.17 \pm 0.04^{\mathrm{a} 1}$ & $7.95 \pm 0.06^{\mathrm{b} 1}$ & $7.68 \pm 0.08^{\mathrm{c} 12}$ & $7.55 \pm 0.05^{\mathrm{c} 1,2}$ \\
\hline \multicolumn{5}{|l|}{ Juiciness } \\
\hline Control & $7.96 \pm 0.06^{\mathrm{a}}$ & $7.67 \pm 0.06^{\mathrm{b}}$ & $7.46 \pm 0.08^{\mathrm{bc}}$ & $7.31 \pm 0.09^{c}$ \\
\hline Flaxseed flour (1\%) & $8.07 \pm 0.08^{\mathrm{a}}$ & $7.85 \pm 0.06^{\mathrm{ab}}$ & $7.65 \pm 0.08^{\mathrm{b}}$ & $7.39 \pm 0.06^{\mathrm{c}}$ \\
\hline \multicolumn{5}{|l|}{ Overall acceptability } \\
\hline Control & $7.78 \pm 0.06^{\mathrm{a}}$ & $7.75 \pm 0.06^{\mathrm{a} 2}$ & $7.53 \pm 0.07^{\mathrm{b} 2}$ & $7.22 \pm 0.07^{\mathrm{c} 2}$ \\
\hline Flaxseed flour (1\%) & $8.17 \pm 0.06^{\mathrm{a}}$ & $8.02 \pm 0.04^{\mathrm{a} 1}$ & $7.73 \pm 0.06^{\mathrm{b} 1,2}$ & $7.46 \pm 0.05^{\mathrm{c} 1}$ \\
\hline
\end{tabular}

* Mean \pm SE with different superscripts row wise (alphabet) and column wise (numeral) differ significantly ( $\mathrm{p}<0.01$ ).

$\mathrm{n}=21$ for each treatment. 
Incorporation of flaxseed flour in extended restructured mutton chops resulted in increased moisture content and thereby higher cooking yield of products. Moisture to protein ratio and shear force value also increased with increase in the level of incorporation of flaxseed flour. Among the sensory attributes, binding, texture and overall acceptability showed increased values with an increase in the level of incorporation of bind enhancing agent (up to $1 \%$ level). Hardness, cohesiveness and springiness of the products increased effectively with the addition of flaxseed flour and lead to an improved overall acceptability. On the basis of physico-chemical characteristics and sensory scores of the products, $1 \%$ level of incorporation was selected as optimum level for the preparation of ERMC and could be successfully added as bind enhancing agent in extended restructured mutton chops. Products incorporated with the optimum level of flaxseed flour $(1 \%)$ were assessed for microbiological quality and it was found that they could be safely stored under refrigeration $\left(4^{\circ} \mathrm{C} \pm 1^{\circ} \mathrm{C}\right)$ in LDPE pouches for 15 days without marked deterioration in sensory and microbiological quality. Therefore, incorporation of flaxseed flour into restructured meat formulation proved to be successful in improving the binding and texture as well as acceptability of the product, which in turn made the product processing economically viable.

\section{REFERENCES}

AOAC. 1995. Official method of analysis. 16th Edn. Association of Official Analytical Chemists, Washington DC.

APHA. 1984. Compendium of method of microbiological examination of food, 2nd Edn. Speck, M.L.American Public Health Association, Washington DC.

Berglund, D. R. 2002. Flax: new uses and demands. Trends in new crops and new uses, ASHS press, Alexandria, VA. pp. 358-360.

Bernal, V. M., C. H. Smajda, J. L. Smith, and D. W. Stanley. 1987. Interactions in protein/polysacchardise/calcium gels. J. Food Sci. 52:1121-1125.

Berry, B. W. and D. W. Stiffler. 1981. Effect of electric stimulator boiling temperature formulation and rate of freezing on sensory cooking chemical and physical properties of ground beef patties. J. Food Sci. 46:1103-1106.

Bilek, E. and S. Turhan. 2009. Enhancement of the nutritional status of beef patties by adding flaxseed flour. Meat Sci. 82:472-477.

Boles, J. A. and P. J. Shand. 1999. Effects of raw binder system, meat cut and prior freezing on restructured beef. Meat Sci. 53:233-239.

Bourne, M. C. 1967. Texture profile analysis. J. Food Sci. 32:6267.

Chen, H. H., S. Xui, and Z. Wang. 2007. Interaction between flaxseed gum and meat protein. J. Food Eng. 80:1051-1059.

Chen, H. H., S. Xu, and Z. Wang. 2006. Gelation properties of flaxseed gum. J. Food Eng. 77:295-303
Chen, H. H., S. Y. Xu, and Z. Wang. 2004. Separation and purification of acidic polysaccharides and neutral polysaccharides in flaxseed gum. J Food Ferment Ind. 1:96100.

Cremer, M. L. and J. R. Chipley. 1977. Satellite food service system: Time and temperature and microbiological and sensory quality of precooked frozen hamburger patties. J. Food Prot. 40:603-607.

Daun, J. K., V. J. Barthet, T. L. Chornick, and S. Duguid. 2003. Structure, composition, and variety development of flaxseed. In: Flaxseed in Human Nutrition (Ed. L. U. Thompson, and S. C. Cunnane). AOCS Press, Champaign, USA, pp. 1-40.

Duncan, D. B. 1955. Multiple range and multiple $F$ test. Biometrics 11:1-42.

Fiscus, A., J. Harris, J. A. Albrecht, and S. E. Scheideler. 1999. Incorporation of flaxseed into a master mix and evaluation of banana bread and peanut butter cookies. J. Am. Diet Assoc. 99(9):A29.

Greene, B. A. and T. H. Cumuze. 1982. Relationship between TBA numbers and inexperienced panelists. Assessments of oxidized flavour in cooked beef. J. Food Sci. 47:52-54.

Holmes, A. W., W. M. Marrs, and M. M. Boyar. 1986. Hydrocolloids and processed food. In: Gums and stabilizers for the food industry (Ed. G. O. Phillips, D. J. Wedlock, and P. A. Williams). 3:245-252. New York: Elsevier Applied Science Publishers.

Jay, J. M. 1996. In: Modern food microbiology (4th ed.). New Delhi: CBS Publishers and Distributors.

Lim, J. 2011. Hedonic scaling: A review of methods and theory. Food Qual. Prefer. 22:733-747.

Lipillina, E. and V. Ganj. 2009. Incorporation of ground flaxseed in bakery products and its effect on sensory and nutritional characteristics-a pilot study. J. Food Sci. 20:50-59.

Modi, V. K., N. S. Mahendrakar, D. Narasima Rao, and N. M. Sachindra. 2004. Quality of buffalo meat burger containing legume flours as binders. Meat Sci. 66:143-149.

Sachdev, A. K. and R. Gopal. 2000. Storage quality changes in cooked chicken rolls. Ind. J. Poult. Sci. 35:364-366.

Singer, F. A. W., F. S. Taha, S. S. Mohamed, A. Gibriel, and M. ENawawy. 2011. Preparation of protein/mucilage products from flaxseed. Am. J. Food. Tech. 6:260-278.

Singh, R., M. K. Chatli, A. K. Biswas, and J. Sahoo. 2011. Quality of omega-3 fatty acids enriched low-fat chicken meat patties incorporated with selected levels of linseed flour/oil and canola flour/oil. J. Food Sci. Technol. (In press)

Snedecor, G. W. and W. G. Cochran. 1995. Statistical methods, 8th edn. IOWA. State University Press, Ames, IOWA.

Tarladgis, B. G., B. M. Watts, M. T. Yaunathan, and L. R. Dugan. 1960. A distillation methods for the quantitative determination of malonaaldehyde in rancid foods. J. Am. Oil Chem. Soc. 37: 44-48.

Trout, E. S., M. C. Hunt, D. E. Johnson, J. R. Claus, C. L. Kastner, and D. H. Kropt. 1992. Characterstics of low fat ground beef containing texture modifying ingredients. J. Food Sci. 57:1924.

Turhan, S., I. Sagir, and N. S. Ustun. 2005. Utilization of hazelnut pellicle in low-fat beef burgers. Meat Sci. 71:312-316.

Turhan, S., H. Temiz, and I. Sagir. 2007. Utilization of wet okara 
in low-fat beef patties. J. Muscle Foods. 18:226-235.

Valencia, I., M. N. O'Grady, D. Ansorena, I. Astiasaran, and J. P. Kerry. 2008. Enhancement of the nutritional status and quality of fresh pork sausages following the addition of linseed oil, fish oil and natural antioxidants. Meat Sci. 80:1046-1054.

Verma, A. K., B. D. Sharma, and R. Banerjee. 2010. Effect of sodium chloride replacement and apple pulp inclusion on the physic-chemical, textural and sensory properties of low fat chicken nuggets. LWT-Food Sci. Technol. 43:715-719.
Wang, Y., D. Li, L. Wang, and B. Adhikari. 2011. The effect of addition of flaxseed gum on the emulsion properties of soybean protein isolate (SPI). J. Food Eng. 104:56-62.

Watts, B. M. 1962. Meat products. Symposium on food lipids and their oxidation. Westport, CT: AVI Pub. Co. Inc. pp. 202

Williams, P. 2007. The role of red meat in the Australian diet. Nutr. Diet 64(s4):S99-S195. 